these foods are considered a delicacy by the Isoko. Palm weevils, the larvas of Rhynchophorus phoenicis, which inhabit the boles of the red-oil palm, are eaten after roasting over an open fire. From personal experience they are very palatable to anyone who enjoys a 'palm-oil stew'.

Snakes of various species and the monitor lizard are also eaten by Isoko farmers when the opportunity arises. The whole of this tasty, if somewhat unusual, diet is washed down on high days and holidays by copious draughts of palm wine, which has been fermented for a number of days. This wine induces the stimulation, followed by sedation, that the Isoko consider essential to full enjoyment of a life pursued under anxious circumstances in an out of the way part of the world.

Nicol, B. M. (1952). Brit. F. Nutr. 6, 34 .

$$
\text { REFERENCE }
$$

\title{
The Diet of Canadian Indians and Eskimos
}

\section{By H. M. Sinclatr, Laboratory of Human Nutrition, University of Oxford}

Apart from racial differences, the Eskimos are unlike the Northern Indians in three respects that concern us. First, the typical Eskimos live on the coast and obtain most of their food from the sea, whereas the Indians live inland. Secondly, the Eskimos frequently eat their food raw whereas this disgusts the Indians who indeed named the Eskimos after this habit: the Cree word uskipoo means 'he eats raw meat'. Thirdly, the Eskimos live mainly north of the tree line, and although they collect some driftwood for sledges and boats they have to depend mainly upon animals, snow and rock for their houses, implements, boats, fuel and clothing; the Indians have access to wood.

\section{The foodstuffs of the Eskimos}

(cf. Amundsen, I908; Birket-Smith, 1936, I947; Egede, 1818; Eisberg \& Owens, 1949 ; Forde, I939 ; Hanson, I942 ; Karavayeva, I938 ; Rasmussen, I927 ; Stefánsson, I913, I9I4, I922, I939 b, $c$, I945, I946 ; Winn, I943 ; Yule, I948.)

Winter. Characteristic hunting is found amongst the Iglulik, Central Eskimos living north of Hudson Bay and in the north of Baffin Land, between latitudes $65^{\circ}$ to $75^{\circ} \mathrm{N}$. The long Arctic winter with a mean temperature of around $-35^{\circ} \mathrm{F}$. and short daylight hours limits activity; thick mists are usual unless dispersed by strong winds which, uninterrupted by trees, cause violent blizzards. As winter begins to set in the Eskimos congregate on the coast or floe ice. The main food throughout the winter is the seal. These animals scratch breathing-holes in the floe in the autumn and maintain them throughout the winter. The Eskimo dog scents them beneath the snow and if they are in use the hunter will fix a piece of bone in the hole which will be disturbed when the seal pushes up its nose to breathe ; then he 
thrusts his harpoon down the hole, plays the seal until it tires, and then enlarges the hole and drags the animal home. This is the so-called máupoq (waiting) hunting-a severe ordeal since the hunter sits absolutely still on a block of snow in the raw cold of the short winter day without having had a meal. Blizzards or fog may prevent hunting for days and, since it is difficult to obtain sufficient seal to last more than a few days, severe shortage of food is common in winter. The seal is the most important animal to the Eskimo, although according to Stefánsson ( $192 \mathrm{r}$ ) it is the most difficult of all north polar animals to get. The two seal mainly hunted from the Bering Strait to northern Greenland are the ringed seal (Phoca foetida) and the barbed seal (Erignathus barbatus). Other seals (such as Cystophora cristata and Phoca groenlandica in the Atlantic, and Arctocephalus ursinus, Histriophoca fasciata and Eumetopias jubatus off Alaska) avoid firm ice and so only approach the shore periodically. The seal provides large quantities of superb fuel for lighting or heating (a $200 \mathrm{lb}$. seal provides nearly $100 \mathrm{lb}$. of blubber in winter) ; it is excellent food for men and dogs ; its skin is used for boats, clothing and containers for oil ; its sinews are used for thread; and the intestines are used for clothing and windows. The Eskimo eats most parts of the seal including the blood; the blubber is not eaten in large amount except in emergencies. The meat, which is very dark, is particularly relished ; it looks extremely lean but according to analysè of F. G. Benedict contains 6-10\% fat (Krogh \& Krogh, I9I4), though Rabinowitch $\&$ Smith (1936) found less.

In Hudson Bay, far far away

From Simpson's choicest torso,

You can get a meal from an Elephant seal,

As pleasant if not more so (Anonymous, not dated).

Spring. The walrus (Odobenus rosmarus in the east and O. obesus in the Bering Sea region), belonging to the same suborder as the seal (Pinnepedia), has somewhat different dietary habits. Whereas the seal eats fish, crustacea, molluscs and even birds, the walrus unearths with its enormous canines the crustacea and molluscs that live on the bottom. Walruses are not hunted until spring when leads of open water appear and the light skin-covered canoe (kayak) is used to harpoon walruses and occasional whales. The contents of the stomach of the walrus are regarded as a delicacy, particularly when they contain the feet of the bivalve Cardium groenlandicum (Vibe, I950). The spring is also a great time for ütoq (stalking) hunting of seals which gather in numbers on the edge of the floes before these break up, and lie basking with their young. At this time of abundance of food, large amounts of blubber are stored in hide bags in pits on the shore beneath rock cairns to protect them from wolverines and foxes. Other animals are hunted in the spring. The polar bear (Thalarctos maritimus), which comes in from the pack ice to eat young seals, is hunted with dog-sledges and brought to bay by releasing the dogs ; its liver is eaten by neither Eskimo nor dog because it is toxic, apparently because of its richness in vitamin A (Rodahl \& Moore, I943; Rodahl, I949). 
The musk ox (Ovibos moschatus) used to be very common, but has rapidly decreased in numbers and become rare or extinct in some areas such as Banks Island where it grazed in large numbers at the beginning of the century. The Canadian Government has banned hunting of the oxen. They are docile, clumsy and slow, and the herd could easily be rounded up and kept at bay by dogs so that the Eskimos, who relish the meat, could kill them with spears. Their rarity is caused by the ease with which they are shot, and the practice of killing the whole herd.

Summer. With the arrival of summer, the dietary changes. Vegetation sprouts, and the Eskimo moves inland to hunt land animals, particularly the caribou (Rangifer arcticus). The herds of these migrate northward at this season taking year by year the same route, and the Eskimos congregate together to drive them into ambushes or marshy ground, or particularly into water where they can be lanced from a kayak as they swim. Unlike the musk oxen, which eat grass, caribou eat mainly mosses and lichens; they provide meat and some fat. The Eskimos are very fond of the fermented and rather sour contents of the caribou paunch; they also eat the faeces either directly or in soup. Other land animals are eaten at this season. Wolves are killed with a sharpened strip of baleen rolled in frozen blubber and hares are snared, and the large summer flocks of birds such as duck and geese which migrate northwards are speared or noosed. Fishing, particularly for salmon (such as Mallotus villosus), is important ; they are usually speared, but sometimes netted or caught on hooks with ivory minnows as bait. In summer the Eskimo ceases to be a strict carnivore. Some berries are eaten : the commonest are black crowberry (Empetrum nigrum var. hermaphroditum), dwarf blueberry (Vaccinium uliginosum var. alpinum), and cloudberry (Rubus chamaemorus). Certain roots (such as Polygonum viviparum), the stalk of the aromatic angelica (Angelica archangelica), some algae, and also the buds and young leaves of the dwarf willow (Salix arctica) are eaten in small amounts. Some berries and leaves (such as Cochlearia officinalis, Oxyria digyna and Epilobium latifolium) are stored for the winter, but in general the consumption is not large.

Geographical variations. Such is the characteristic dietary pattern of the typical Eskimo. Variations will depend upon locality. The Eastern Eskimos of Greenland and the Western Eskimos from the Mackenzie river to the eastern tip of Siberia hunt seals using the kayak and whales with the kayak or umiak. The most important item of food of the Polar Eskimos is the narwhal (Monodon monoceros). It feeds mainly on polar cod (Gadus saida), Greenland halibut (Rheinhardtius hippoglossoides) and large numbers of shrimps (Decapoda). It is hunted almost exclusively from the kayak, and according to Vibe (1950) 'The whole existence of the Polar Eskimos depends on the catch of this animal, since they get all their necessaries of life from it'. The skin (mattak) is greatly relished and tastes like hazel-nuts ; it is eaten raw and contains considerable amounts of glycogen and ascorbic acid. The White whale (Delphinapterus leucas) is almost as important, but it is more shy and much harder to catch ; its diet is similar except that it does not consume decapods. Ice-hunting as I have described above is mainly practised by the Central Eskimo. The Caribou Eskimo, for instance the Ihalmiut very recently described 
by Mowat (1952), live inland and so depend almost entirely during the winter on caribou meat obtained as the herds migrate southwards in autumn, and kept frozen or dried. For any true Eskimo the winter is likely to be a period of privation. But many Eskimos, like the Indians to be mentioned shortly, have become contaminated by white traders or missionaries, and supplied with white flour, sugar and tea.

Preparation of food. As already mentioned, the Eskimos often eat their food raw, sometimes frozen, sometimes thawed. Cooking when done consists of boiling or occasionally roasting, never frying. Caribou meat and fish are eaten raw, and are preferred when they are rotten; caribou and fish heads are boiled. The caribou liver is allowed to ferment inside the moss-filled caribou stomach under a hot sun for some days before being eaten; probably all its glycogen breaks down. Seal is lightly boiled over a lamp of seal oil, blood being added to make soup after the cooked meat has been taken from the pot ; if eaten raw, seal is eaten frozen. Dried meat with fat may be pounded into pemmican; this foodstuff has been praised by Stefánsson (1944) but was found very unsatisfactory by his colleague Hadley (Stefánsson, 192I) and by others (cf. Kark, Johnson \& Lewis, r 945). Large quantities of water are drunk during a meal which, like most aspects of Eskimo life, is unhygienic - face, hands and clothing get smeared with fat and gravy, and those eating do not necessarily leave the meal to urinate. Food is distributed from the common dish to all present, usually in a definite order ; but there are a number of food taboos particularly concerning the young. The evil of not sharing the catch with those too old or young or ill to hunt is illustrated by the widespread folklore tale of the boy who hunted at frozen-up breathing-holes (Holtved, 195I) : a feeble old woman and her young grandson were being left out of the common distribution of the short supply of food and began to starve ; the old woman tried to catch food around the hut, but caught nothing except the refuse that lies thick in the snow. So she made a harpoon for the boy and asked the hunters to lead him to a frozen-up (and therefore unused) breathing-hole. The boy sat there knowing no better, but suddenly an enormous seal broke through the ice to breathe. He speared it and with the help of the old woman brought it home and ate it. The others caught nothing. Thereafter the boy and the old woman had regular catches which they rightly did not share with the others, who continued to catch nothing and starved to death.

\section{The nutritional value of the Eskimo diet}

In 1855 Rink $(1857,1877)$ made a statistical study of the annual food consumption of the 6100 Eskimos in the Southern Inspectorate of Greenland. This district was south of the area of dog sledges, and since there were no domesticated animals it was easier to estimate how much of the indigenous food resources was consumed by man. Rink estimated that about $40 \%$ of the Eskimos were below I 5 years of age and $0.3 \%$ above 60 years ; $48 \%$ were males and $52 \%$ females. The main foodstuff was seal meat and the next most important was the capelin (Mallotus villosus); this small salmon visits the shores of Greenland in large shoals in July and is dried whole and stored. Some berries (Vaccinium uliginosum) and 
unknown quantities of mussels, seaweed and angelica were included in the ' native' diet which was supplemented with bread and flour, barley and peas, sugar and coffee bought from Europeans. Krogh \& Krogh (I9I4) took this population as corresponding to 5000 adults, and estimated thereby the daily food consumption of an adult. Guessing a factor for wastage and using analyses partly done for them by F. G. Benedict, they then calculated the aliments and calories in the daily diet :

$\begin{array}{lr}\text { Protein (g) } & \mathbf{2 8 2} \\ \text { Carbohydrate (g) } & 54 \\ \text { Fat (g) } & \mathrm{r} 35 \\ \text { Calories (Cal.) } & 2640\end{array}$

As Krogh \& Krogh pointed out, the figures could ' easily be $10 \%$ and possibly even $20 \%$ wrong or more' ; the factor for wastage in preparation and storage was particularly doubtful. For instance they assumed a loss of $50 \%$ in capelins, which are eaten whole-heads, bones and skin-since 'a considerable part is no doubt lost during the time they are kept in a preserved state'. It is difficult to see what they lose ; the dried fish kept in a cache under the snow may well retain a considerable amount even of their ascorbic acid.

It is worth extending the analysis of Rink's ( 1857 ) figures further with the gross errors fully in mind. The estimation of ' food moving into civilian consumption' is not a method by which nutriture can be assessed (Sinclair, 1948a) ; and in most instances no suitable food analyses are available even for fresh foods. The Eskimos eat seal meat lightly boiled usually in sea water ; there may be only trivial loss of ascorbic acid and unknown dietary additions of calcium and other salts (of course no sodium chloride as such is added to the diet). Meat and fish are frequently eaten raw and after considerable putrefaction; eggs are eaten raw at any stage of incubation : no guess is profitable about the effect on vitamins of the $B$ complex but it is certain that much of the glycogen, which has usually been taken to represent about half the total dietary carbohydrate (Krogh \& Krogh, 1914), will have broken down, but the products are presumably used. On the other hand, when a seal is caught the liver is often eaten quickly; in the calculations below no account has been taken of the viscera of the seal that are eaten except for vitamin A (seal liver contains 75,000 i.u. and seal oil 7000 i.u./100 g (Heller, 1949)) ; the zero figure for vitamin $D$ in the seal as eaten given in Table $I$ is obviously wrong. But it is preferable that guesses should err by being underestimates. With these gross limitations in mind therefore, an estimate of the nutritional value of the dietary of an adult Eskimo living in the Southern Inspectorate of Greenland in I 855 may be made (Table $\mathrm{I}$ ). The table gives for purposes of comparison the standards of the Oxford Nutrition Survey for a moderately active man (Sinclair, I $948 b$ ) ; Table 2 gives the modern per capita consumption of aliments by Greenlanders (Bertelsen, 1935-43) when about $65 \%$ of the food is imported from Europe. Little comment is needed. Carotenoids are of course irrelevant since the ingestion of vitamin $\mathrm{A}$ is so high. The figure for calcium is a gross underestimate since no 


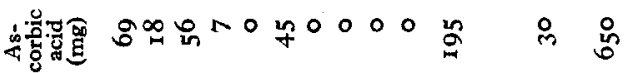

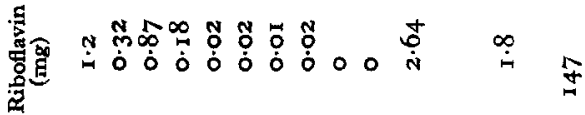

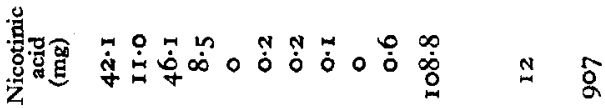

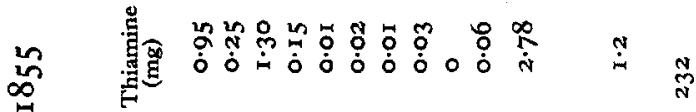

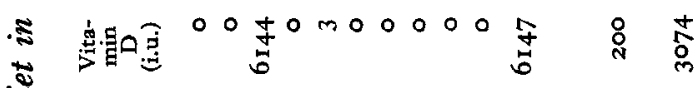
胥 8 迹

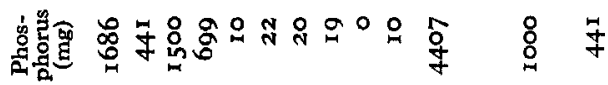

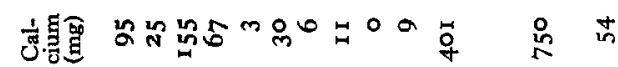

๘

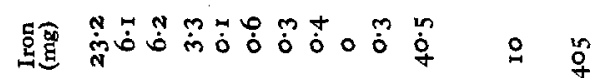

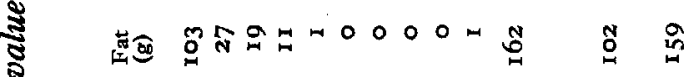

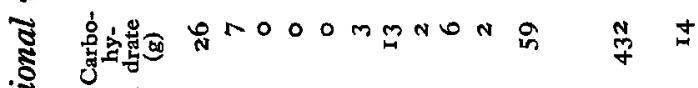

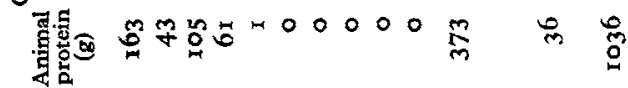

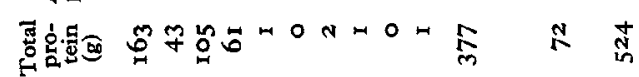

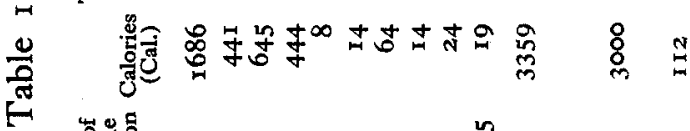

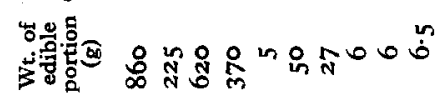

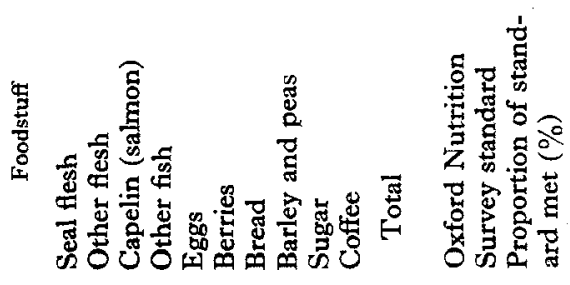


Table 2. Modern per capita consumption ( $g$ ) of aliments daily by Greenlanders (Bertelsen, 1935-43)

\begin{tabular}{|c|c|}
\hline Season & Origin \\
\hline Seal-hunting & $\begin{array}{l}\text { Imported } \\
\text { Indigenous } \\
\text { Total }\end{array}$ \\
\hline Fishing & $\begin{array}{l}\text { Imported } \\
\text { Indigenous } \\
\text { Total }\end{array}$ \\
\hline
\end{tabular}

$\begin{array}{cccc}\begin{array}{c}\text { Protein } \\ (\mathrm{g})\end{array} & \begin{array}{c}\text { Carbohydrate } \\ (\mathrm{g})\end{array} & \begin{array}{c}\text { Fat } \\ (\mathrm{g})\end{array} & \begin{array}{c}\text { Calories } \\ \text { (Ca1.) }\end{array} \\ 42 & 437 & 25 & 2196 \\ 125 & 20 & 79 & 1330 \\ 167 & 457 & 104 & 3526 \\ 42 & 437 & 25 & 2196 \\ 306 & 0 & 12 & 1367 \\ 348 & 437 & 37 & 3563\end{array}$

allowance has been made for sea water consumed or for the bones eaten; the figure for vitamin D (overestimated probably in fish but underestimated in meat) is very high. Little of the iron ingested is absorbed : seal meat is almost black probably because of a high content of myoglobin ; so are the Eskimo faeces which are easily inspected around their huts. Ascorbic acid is high : though the berries are often swallowed whole and pass through the gut unaltered and though raw meat has often decomposed, the practices of eating raw the flesh, skin and viscera of animals that have a high content of ascorbic acid (Bertelsen, I9I I Høygaard \& Rasmussen, I939; Anonymous, 1950) and of eating the moss and lichens in the acid contents of the caribou pouch (though these are often fermented) must provide considerable amounts of ascorbic acid ; further, no allowance has been made for sea algae which contain $10-50 \mathrm{mg} / \mathrm{ro0} \mathrm{g}$ (Høygaard, 1938). We may cheerfully conclude that there was an abundance of nutrients in the Eskimo dietary of a century ago, and pass to consider further the aliments.

The requirement of the Eskimo for aliments is obviously increased by his cold environment : he has no heating in his hut except for that derived from cooking and lighting ; his heat loss is diminished by his relatively low surface area, by his layer of subcutaneous fat and by his efficient clothing. But he loses a considerable amount of heat with each breath he takes. Heat is required for warming and for humidifying inspired air, and the amount is large : a man whose energy metabolism is 3000 Cal. daily exclusive of that necessary to warm and humidify the inspired air would require an expenditure of $4073 \mathrm{Cal}$. daily at an average temperature of $-40^{\circ} \mathrm{F}$. (Webster, 1947). The consumption of a meal of frozen meat incurs a loss of heat : $4 \mathrm{~kg}$ of meat at $-40^{\circ} \mathrm{F}$. eaten in a day adds about 300 Cal. to the daily energy expenditure. His activity is difficult to estimate : hunting and travelling may be strenuous, but a good deal of time is spent eating, sleeping or sitting. His basal metabolic rate has interested a number of people. Some (e.g. Levine, 1949) have pronounced it normal ; others (e.g. Brown, 195I) have found it increased : Rabinowitch \& Smith (1936) found the average increase in ten Eskimos $+26 \%$, and this they attributed to increased muscle tone and the specific dynamic action of protein (Krogh \& Krogh (1914) thought the specific dynamic action was remarkably low in the Eskimos they studied). There is in fact nothing unusual about the total intake of aliments ; it is the very high protein, very low carbohydrate and 
high fat intakes that have excited interest. It is, however, worth noting that according to the customary convention (Woodyatt, I92I ; Shaffer, I92I) this diet is not ketogenic since the ratio of ketogenic(FA) to ketolytic $(G)$ aliments is I.09. Indeed, the content of fat would have to be exactly doubled ( $324 \mathrm{~g}$ daily) to make the diet ketogenic $(\mathrm{FA} / \mathrm{G}>\mathrm{I} \cdot 5)$.

The Eskimo is apparently able to digest and absorb very large amounts of protein and fat at a single meal. In times of plenty, $4 \mathrm{~kg}$ of meat daily is a common amount and much is taken at a single meal : they do not usually take food in the morning. Consumption of larger amounts such as $15 \mathrm{~kg}$ has been observed on occasion, and Ross (1835) considered that an Eskimo 'perhaps eats twenty pounds of flesh and oil daily', which I suppose is possibly 46,000 Cal. Parry (1 824) thought he would test the capacity of an adolescent Eskimo ; the food was weighed and, apart from fluids, he ate in $20 \mathrm{~h} 8 \frac{1}{2} \mathrm{lb}$. meat and $\mathrm{i} \frac{3}{4} \mathrm{lb}$. bread (about $15,700 \mathrm{Cal}$.) and 'did not consider the quantity extraordinary'. But this is trivial compared with the feats of the Siberian Yakuti who eat $25-30 \mathrm{lb}$. meat daily, and there is no record approaching the $35 \mathrm{lb}$. of beef and $18 \mathrm{lb}$. of butter (providing about I I2,000 Cal. and occupying a volume of the order of $5 \frac{1}{2}$ gal.) alleged to have been eaten in less than $3 \mathrm{~h}$ by each of two Yakuti (Simpson, I847.)

\section{Eskimo metabolism, nutriture and health}

(cf. Alexander, 1949; Barnett, Fields, Milles, Silverstein \& Bernstein, 1947; Bermudez, $195^{\circ}$; Brown, Sinclair, Cronk \& Clark, 1948 ; Brown, Sinclair, Cronk \& deSinner, 1949a ; Crile \& Quiring, 1939; Ehrström, 1950a, c ; Hatcher, Page \& Brown, 1950 ; Heinbecker, 1928, 1932-3 ; Higgins, Peabody \& Fitz, I916 ; Levine, 1942; Lieb, 1926 ; Lockhart, I945; McCann, 1950; McClellan \& Du Bois, I930 ; Mould, 1940 ; Payne \& Sexton, 1949 ; Pedersen, 1947 ; Roberts, 1943 ; Rodahl \& Edwards, 1952 ; Sinclair, Brown, Cronk \& Clark, I948; Sinclair, Brown, Cronk \& deSinner, 1949; Stefánsson, 1918, 1939a; Thomas, 1927; Urquhart, 1935 ; Waagstein, 195I ; Waugh,1933 ; Wells, 1933; Wells \& Heinbecker, 1932 ; Wilson, 1945.)

The high ingestion of protein alters blood and urinary composition : nonprotein nitrogen and amino-acids are raised in plasma, and urinary nitrogen is increased (Rabinowitch \& Smith, 1936), even during fasting (Heinbecker, 1931); plasma protein has been found to be normal by all observers. The fairly high ingestion of fat appears to raise somewhat the lipid constituents of the blood (Sinclair, Brown \& Cronk, 1949), although the results are not consistent: Corcoran \& Rabinowitch (1937) made claims that do not appear to be supported by a statistical analysis of the figures they give (which is not assisted by errors in their table of means if the individual figures they give are correct); Wilber \& Levine (1950) claimed higher values than normal but did not state the age of their subjects ; Brown (195I) found normal values. The main interest of these lies in the cholesterol. Keys and others have shown that increased fat in the diet tends to increase cholesterol in serum (Keys, $195^{2}$; Keys, Mickelsen, Miller \& Chapman, 1950 ; Hildreth, Mellinkoff, Blair \& Hildreth, $195 \mathrm{r}$ ), and therefore probably to increase the incidence 
of arteriosclerosis ; Tolstoi (1929) claimed lipaemia and increased cholestrol in two men who lived for I year on lean and fat meat, but an inspection of his figures shows that there was in fact no increase in cholesterol in one of the two. From the scanty data available, it appears that the true Eskimos consume an unusually high quantity of fat but that their serum total cholesterol is normal (cf. Garn \& Gertler, 195I) ; the matter requires further investigation. Corcoran \& Rabinowitch (1937) concluded that meat-eating Eskimos had a very active and unusual mechanism for utilization of fats ; part of their evidence was that the ratio of phospholipids to total cholesterol rose in two subjects after ingestion of $200 \mathrm{ml}$. of soya-bean oil, but this is not in accord with the figures they give. To the unusual mechanism they attributed the absence of ketosis in the Eskimo. Tolstoi's (1929) two men had ketonuria over the entire period of the experiment, despite the $\mathrm{CO}_{2}$ combining power of plasma remaining within normal limits ; these men of course were not Eskimos. The serum lipids increased in four Eskimos in Southampton Island who subsisted for 6 days exclusively on pemmican $(75 \%$ of calories from fat), and increased further when they fasted ; ketonuria developed during the fast only (Sinclair, Brown \& Cronk, 1949). The ketonuria of U.S. soldiers in the Arctic on normal rations has been attributed to the general adaptation syndrome (Kark, Johnson, Bly \& Consolazio, 1949; Sargent \& Consolazio, 1951).

We may conclude from the above that, provided the Eskimo can catch his normal sources of food, his diet is adequate; when the animals are scarce or conditions such as fog prevent hunting he often starves. It is generally agreed that rickets and scurvy are unknown, the former despite the meagre sunlight and pigmentation of the skin. Brown (195I) states that 'the most frequently occurring clinical signs in the Eskimo population as a whole were ascorbic acid deficiency and riboflavin deficiency', but these signs are not specific and strong exception can be taken to the statement as it stands ; the full publication of his interesting observations is eagerly awaited. There is no evidence that the high-protein diet causes any ill-health. The subjects are plethoric, often with epistaxis ; this was found unexpectedly by Rabinowitch (1936) who however had not read Krogh \& Krogh (1914); Rabinowitch(1936) noted polycythaemia ; Peacock (1947) mentions the frequency of haemoptysis without evidence of tuberculosis : but it is not proved that these signs are caused by the high-protein diet. Krogh \& Krogh (1914) found that there was a considerable storage of protein when much meat was ingested after a diet poor in nitrogen. This storage in the liver might cause enlargement ; Brown (I95I) and Brown, Sinclair, Cronk \& deSinner ( $1949 b$ ), however, found that the common hepatomegaly appeared to be caused by increased carbohydrate, most probably glycogen, and the enlarged livers were decreased in size by something in milk other than casein, five vitamins of the B complex or lactose.

The problem of cholesterol and atherosclerosis has been mentioned above. Wilber \& Levine (1950) concluded that 'In the Alaskan Eskimos ... there is a consistently high serum cholesterol on the one hand ; repeated clinical surveys, on the other, indicate an almost total absence of cardiovascular-renal diseases in the population' [their means are, however, $203 \mathrm{mg} / \mathrm{r} 00 \mathrm{ml}$. serum for males and 234 for 
females which, despite the ages not being stated, would hardly appear high from the data of Keys (1949)]. Others have commented on this absence in the Eskimo on his customary diet, but Rabinowitch (1936) believed he had 'definitely disproved the alleged incidence of arteriosclerosis in the Eskimo, at least in the Eastern Arctic'; his data seem to show that it was common in those Eskimos consuming our diet but there was no evidence of arteriosclerosis in the most northerly parts he visited where the true Eskimo dietary was practised. The same seems to be true of tuberculosis, diabetes mellitus, appendicitis, cancer and dental caries, although tuberculosis is becoming a severe problem (Lewis \& Wherrett, 1947). Parasitism, including trichinosis, is extremely common (Brown, Green, Boag \& Kuitunen-Ekbaum, $195^{\circ}$; Brown, Sinclair, Cronk \& Clark with Kuitunen-Ekbaum, I948 ; Brown, Cronk, deSinner, Green, Gibbons \& Kuitunen-Ekbaum, I949a ; Brown, Cronk, deSinner, Green, Gibbons \& Kuitunen-Ekbaum, 1949b; Hitchcock, 1950; Roth, 1949).

We may picture the true Eskimo, then, as a person who has adapted with extraordinary efficiency to subsisting in the Arctic as a typical carnivorous animal, and who is peaceful, extremely happy and healthy (except for occasional periods of starvation). But contact with white traders, trappers and missionaries is causing malnutriture and ill-health, as has happened extensively in the Indians. The contamination of these may now be considered.

\section{The foodstuffs of the Indians (cf. Jenness, 1932)}

The Indians extend, or extended, over a wide area. Some, for instance the Iroquois and Hurons, were agricultural ; some, for instance the Ojibwa, lived in the central forest area on deer, berries and nuts ; the Athabascans lived mainly on caribou and the Blackfoot of the Plains on bison (' buffalo') until these were exterminated 70 years ago. The Cree lived partly in the Plains on bison and antelope, partly in the bush on caribou, moose, beaver, bear and hares. As soon as they obtained firearms they expanded west and north, and became very powerful. A disastrous epidemic of smallpox in 1784 reduced them, and the introduction of alcohol demoralized them ; they were frequently attacked by the Blackfoot, and finally decimated by a second epidemic of smallpox in 1838 . Their downfall has been completed by introductions from the dietary of our proud Western civilisation : flour, sodium bicarbonate, lard, sugar and tea. The former three ingredients are mixed in haphazard proportions and baked into bannock.

\section{Indian nutriture}

(cf. Duncan, 1947 ; Fritz \& Thygeson, 195I ; Fritz, Thygeson \& Durham, 195 I ; Thygeson \& Fritz, 195 I.)

In 1943 I had the privilege, at the invitation of the Canadian Government and the R.C.A.F., of joining Dr Tisdall and Dr Kruse to investigate conditions amongst the Bush Cree at Norway House ; the Acting Superintendent of the Medical Service of the Indian Affairs Branch (Dr P. E. Moore) organized the expedition which was joined by the Medical Superintendent at Norway House (Dr Corrigan) and the 
consultant in ophthalmology to the R.C.A.F. (Dr Nicholls). The Indians investigated used to subsist on caribou, moose, beaver, musk-rat, hare and fish, with a few berries. The food was cooked and the viscera were eaten. A survey the previous year (Moore, Kruse, Tisdall \& Corrigan, 1946) had suggested that about $85 \%$ of the calories in the food purchased came from white flour, lard, sugar and jam ; ' every Indian observed had some abnormality of the conjunctivae, ocular limbic blood vessels, tongue or gums ... These changes have been attributed by one of the authors (H.D.K.) to a lack of vitamin A, vitamin $B_{2}$ and vitamin $C$ respectively'.

In the later survey, I had the opportunity of examining clinically $13^{8}$ males and ro2 females, mainly in the age-groups 7-14 years and 20-44 years; 162 Indians were examined with a slit-lamp microscope. On the basis of the clinical examination the nutriture was rated markedly poor in $8 \%$; two persons were considered to show mild deficiencies of riboflavin, and one other person was considered to show mild deficiency of nicotinic acid. The skin was frequently dry $(23 \%)$ and thickened $(15 \%)$, and folliculosis was fairly common (23\%); half the boys in the age-groups 7-I4 and I5-19 years had folliculosis-a condition which is common at these ages particularly if hygiene is neglected. There was no reason to attribute these changes to nutritional deficiency. The most interesting changes were in the eyes. In subjects examined with the slit-lamp microscope, conjunctival opacity was common at all ages after infancy $(24 \%)$, pingueculae were extremely common $(76 \%)$, no Bitot's spots were seen, and pterygia occurred in $30 \%$ and were even found in two persons of 19 years ; they were twice as common in males. Mild active superficial keratitis occurred in $9.3 \%$ and marked in $\mathrm{x} \cdot 2 \%$; phlyctenular keratoconjunctivitis occurred in about $2 \%$. These changes in the eyes were attributed by me mainly to exposure, injury (including smoke) and (with phlyctenules) tuberculosis rather than vitamin deficiency; some persons gave clear histories of lime burns years earlier and the superficial keratitis was often only in the eye known to have been affected. The pterygia could reasonably be attributed to exposure to the cold wind and glare. Full details will be published in due course.

\section{Discussion}

The Eskimos used to subsist on a carnivorous diet, eating meat raw or lightly cooked with sea water, and consuming heads, skin, viscera, marrow, blood and stomach contents. This was an excellent dietary adequate in all respects and only failing when the hunting of seals or other animals was prevented. Despite almost complete lack of hygiene they enjoyed a healthy happy life. The Bush Indians fared similarly upon cooked meat with some berries and nuts. The introduction of the white man's diet in return for his exploitation of the furs and extermination of the buffalo changed matters. The Indian has so far been most affected, but wherever the white man contaminates the Eskimos, the diseases of civilization follow. The expectation of life amongst the Eskimos in north Greenland is only 25 years in men and 27 years in women (Ehrström, 1950b). Tuberculosis is responsible for nearly half the deaths of Eskimos and Indians in Alaska (Haldeman, I95 I) 
and is very prevalent elsewhere ; if it produces phlyctenular keratitis, efficiency as a hunter or trapper is seriously reduced and so are the chances of obtaining a meagre existence. Other diseases that are common amongst civilized persons appear despite the inadequacy of the diet of bannock and our association of these diseases with a high standard of living : arteriosclerosis, diabetes mellitus and malignant disease.

Fortunately the Danish, Canadian and U.S. Governments have taken active and most praiseworthy steps to study and to protect these peoples. There remains much to be learnt from the investigation of their nutrition.

\section{SUMMARY}

I. The Eskimo is a typical carnivorous animal subsisting largely on raw meat and fat.

2. A rough calculation of the nutritional value of the supposed dietary of a typical adult Eskimo a century ago indicates that it was adequate in all known respects.

3. The typical dietary is very high in protein. It is high in fat and low in carbohydrate, but would not be expected to be ketogenic. The nutriture and health of the Eskimo subsisting on it are briefly discussed.

4. The Bush Indians lived on cooked meat with some berries and nuts. But their dietary is now mainly bannock (white flour, lard and sodium bicarbonate).

5. A brief description is given of the nutriture of Bush Indians as observed in March 1943 .

6. The sad fate of the Eskimos and Indians when contaminated by white men is mentioned.

I am grateful to the Canadian Government and to the late Dr F. F. Tisdall (then Nutritional Consultant to the R.C.A.F.) for inviting me to Canada in I943. I thank Surg. Lt. Cmdr. B. Geoghegan, R.N., for much help with the bibliography.

\section{REFERENCES}

Alexander, F. (1949). Nerv Engl. F. Med. 240, ro35.

Amundsen, R. (1908). The North West Passage. London : Constable.

Anonymous (1950). Priroda no. 10, p. 53. Quoted by Nutr. Abstr. Rev. 22, I 24.

Anonymous (n.d.). Sure-fire Sue, a Sequel to Eskimo Nell, a Tale of the Frozen North (unpublishable).

Barnett, H. E., Fields, J., Milles., G., Silverstein, G. \& Bernstein, A. (1947). F. Amer. med.Ass. 135, 500.

Bermudez, M. (1950). Rev. Sanid. Hig. publ., Madr., 24, 559.

Bertelsen, A. (191 1). Hospitalstidende, 54, 537.

Bertelsen, A. (1935-43), Medd. Gronland. II7, 1.

Birket-Smith, K. (1936). The Eskimos, London: Methuen.

Birket-Smith, K. (1947). F. R. anthrop. Inst. 77, 145 .

Brown, G. M. (195I). Progress Report on Clinical and Biochemical Studies of the Eskimo. Canada, Department of National Defence, Defence Research Board, Rep. no, DR 4I.

Brown, M., Green, J. E., Boag, T. J. \& Kuitunen-Ekbaum, E. (r950). Canad. F. publ. Hlth, 4r, 508.

Brown, M., Sinclair, R. G., Cronk, L. B. \& Clark, G. C. (1948). Canad. med. Ass. F. 58, 9 I.

Brown, M., Sinclair, R. G., Cronk, L. B., Clark, G. C. (with Kuitunen-Ekbaum, E.) (1948). Canad.

7. publ. Hlth, 39, $45 \mathrm{I}$.

Brown, M., Sinclair, R. G., Cronk, I. B. \& deSinner, F. (1949a). Canad. med. Ass. F. $60,86$.

Brown, M., Sinclair, R. G., Cronk, L. B. \& deSinner, F. (1949b). Canad. med. Ass. F. 60, 86. 
Brown, M., Cronk, B., deSinner, F., Green, J. E., Gibbons, J. E. \& Kuitunen-Ekbaum, E. (I949a). Canad. F. publ. Hlth, 40, 20.

Brown, M., Cronk, L. B., deSinner, F., Green, J. E., Gibbons, J. E. \& Kuitunen-Ekbaum, E. (1949b). Canad. F. publ. Hlth, $40,508$.

Corcoran, A. C. \& Rabinowitch, I. M. (1937). Biochem. $\mathscr{7} .31,343$.

Crile, G. W. \& Quiring, D. P. (1939). F. Nutr. 18, 36r.

Duncan, A. C. (1947). Lancet, 253, 919.

Egede, H. (1818). A Description of Greenland. London : Allman.

Ehrström, M. C. (1950a). Nord. med. 44, 1750 .

Ehrström, M. C. (1950b). Acta med. scand. 140, 239.

Ehrström, M. C. (1950c). Acta med. scand. 140, 254.

Eisberg, H. B. \& Owens, J. E. (1949). Fundamentals of Arctic and Cold Weather Medicine and Dentistry. Washington : U.S. Navy Department, Research Division, Bureau of Medicine and Surgery. Rep. no. NAVMED I307.

Forde, C. D. (1939). Habitat, Economy and Society, 3rd ed. London : Methuen.

Fritz, M. H. \& Thygeson, P. (1951). Publ. Hlth Rep., Wash., 66, 934.

Fritz, M. H., Thygeson, P. \& Durham, D. (1951). Amer. 7. Ophthal. 34, 177.

Garn, S. M. \& Gertler, M. M. (195I). Canad. med. Ass. F. 64, 338.

Haldeman, J. C. (195I). Publ. Hlth Rep., Wash., 66, 912.

Hanson, E. P. (1942). Reconnaissance Report on Concentrated Rations of Primitive Peoples. Washington: Office of the Quarter Master General.

Hatcher, J. D., Page, J. \& Brown, M. (1950). Rev. canad. Biol. 976.

Heinbecker, P. (1928). F. biol. Chem. 80, 46r.

Heinbecker, P. (I931). F. biol. Chem. 93, 327.

Heinbecker, P. (1932-3). F. biol. Chem. 99, 279.

Heller, C. A. (1949). F. Home Econ. 4I, 177.

Higgins, H. L., Peabody, F. W. \& Fitz, R. (1916). F. med. Res. 34, 263.

Hildreth, E. A., Mellinkoff, S. M., Blair, G. W. \& Hildreth, D. M. (1951). Circulation, 3, 641.

Hitchcock, D. J. (I950). F. Parasit. 36, 232.

Holtved, E. (1951). Medd. Gronland, 152, no. 2, p. I.

Høygaard, A. (1938). Lancet, 235, 758.

Høygaard, A. \& Rasmussen, H. W. (1939). Nature, Lond, r43, 943.

Jenness, D. (1932). Bull. Nat. Mus. Can. no. 65.

Karavayeva, T. (I938). Sovetsk. Arkt., p. I02.

Kark, R. M., Johnson, R. E., Bly, C. G. \& Consolazio, C. F. (1949). F. Lab. clin. Med. 34, 1616.

Kark, R. M., Johnson, R. E. \& Lewis, J. S. (1945). War Med., Chicago, 7, 345.

Keys, A. (1949). Fed. Proc. 8, 523.

Keys, A. (1952). Circulation, 5, II 5 .

Keys, A., Mickelsen, O., Miller, E. v. O. \& Chapman, C. B. (1950). Science, 112, 79.

Krogh, A. \& Krogh, M. (I9I4). Medd. Gronland, 51, I.

Levine, V. E. (1942). Fed. Proc. I, 12 I.

Levine, V. E. (1949). Amer. F. phys. Anthrop. 7, 278.

Lewis, H. W. \& Wherrett, G. J. (1947). Canad. med. Ass. F. 57, 357.

Lieb, C. W. (1926). F. Amer. med. Ass. 87, 25.

Lockhart, E. E. (1945). Proc. Amer. phil. Soc. 89, 235.

McCann, M. E. (1950). Canad. Nurse, 46, 626.

McClellan, W. S. \& Du Bois, E. F. (1930). F. biol. Chem. 87,65 I.

Moore, P. E., Kruse, H. D., 'Tisdall, F. F. \& Corrigan, R. S. C. (1946). Canad. med. Ass. F. 54, 223.

Mould, W. L. (r940). Arch. Ophthal., N.Y., 24, 972.

Mowat, F. (1952). People of the Deer. London: Michael Joseph.

Parry, W. (1824). Fournal of a Second Voyage for the Discovery of a North-West Passage from the Atlantic to the Pacific; Performed in the Years 1821-22-23, in His Majesty's Ships Fura and Hecla. London: Murray.

Payne, R. C. \& Sexton, R. L. (1949). Amer. F. dig. Dis. 16, 297.

Peacock, F. W. (1947). Canad. med. Ass. F. 56, 328.

Pedersen, P. O. (1947). Proc. R. Soc. Med. 40, 726 .

Rabinowitch, I. M. (1936). Canad. med. Ass. 7. 34, 487.

Rabinowitch, I. M. \& Smith, F. C. (1936). F. Nutr. 12, 337.

Rasmussen, K. (1927). Across Arctic America. London : Putnam.

Rink, H. (1857). Gronland, Geographisk og Statistisk Beskrevet. Copenhagen: Det sydlige Inspektorat.

Rink, H. (1877). Danish Greenland: Its Peoples and Its Products. London : King.

Roberts, B. B. (1943). Polar Rec. 4,63. 
Rodahl, K. (1949). Nature, Lond., I64, 530.

Rodahl, K. \& Edwards, J. Jr. (1952). The Body Surface Area of Eskimos as Determined by the Linear and Height Weight Formulae. A.M.R.L. Ladd. AFB Project 22-1301-000I, part I.

Rodahl, K. \& Moore, T. (1943). Biochem. F. 37, 166.

Ross, J. (1835). Narrative of a Second Voyage in Search of a North-West Passage and of a Residence in the Arctic Regions During the Years 1829, 1830, 1831, 1832, 1833. London: A. W. Webster.

Roth, H. (1949). Nature, Lond., 163, 805.

Sargent II, F. \& Consolazio, C. F. (1951). Science, 113, 63 I.

Shaffer, P. A. (1921). F. biol. Chem. 49, 143.

Simpson, G. (1847). Narrative of a Fourney Round the World, during the Years 1841 and 1842 . London : Colburn.

Sinclair, H. M. (1948a). Vitam. \& Horm. 6, ror.

Sinclair, H. M. (1948b). Investigations of the Oxford Nutrition Survey Team in Malnutrition and Starvation in Western Netherlands September 1944-Fुuly 1945, p. 140. The Hague : General State Printing Office.

Sinclair, R. G., Brown, G. M. \& Cronk, L. B. (1949). Fed. Proc. 8, 25 I

Sinclair, R. G., Brown, G. M., Cronk, L. B. \& Clark, G. C. (1948), Canad. med. Ass. F. 58, 93.

Sinclair, R. G., Brown, M., Cronk, L. B. \& deSinner, F. (1949) Canad. med. Ass. F. 6o, 87.

Stefánsson, V. (1913). My Life with the Eskimo. New York : The Macmillan Co.

Stefánsson, V. (1914). Anthrop. Pap. Amer. Mus. 14, I.

Stefánsson, V. (1918). F. Amer. med. Ass. 71, 1715.

Stefánsson, V. (192, r). The Friendly Arctic. London: Macmillan and Co.

Stefánsson, V. (1922). Hunters of the Great North. New York : Harcourt Brace.

Stefánsson, V. (1939a) Science, 89, 484 .

Stefánsson, V. (1939b) Adventures in Diet. Chicago: American Institute of Meat Packers.

Stefánsson, V. (1939c). Med. Rec., N.Y., 148, I.

Stefánsson, V. (1944). Milit. Surg. 95, 89 .

Stefánsson, V. (1945). Living on the Fat of the Land. Harpers Magazine.

Stefánsson, V. (1946). Not by Bread Alone. New York: The Macmillan Co.

Thomas, W. A. (1927). 7. Amer. med. Ass. 88, 1559.

Thygeson, P. \& Fritz, M. H. (195I). Amer. F. Ophthal. 34, 357.

Tolstoi, E. (1929). $\mathscr{F}$. biol. Chem. 83, 753.

Urquhart, J. A. (1935). Canad. med. Ass. F. 33, 193.

Vibe, C. (1950). Medd. Gronland, r50, no. 6 p. I.

Waagstein, P. H. D. (195I). Ugeskr. Læg. I13, 1020.

Waugh, L. M. (1933). $\mathscr{Y}$. dent. Res. $13,149$.

Webster, A. P. (1947). Caloric Requirements of Man in Cold Climates: Theoretical Considerations. U.S.Navy Department, Research Division, Bureau of Medicine and Surgery, Rep. NM or 3009.

Wells, J. R. (1933). Amer. F. Hyg. 18, 656.

Wells, J. R. \& Heinbecker, P. (1932). F. infect. Dis. 50, 281.

Wilber, C. G. \& Levine, V. E. (1950). Exp. Med. Surg. 8, 422.

Wilson, E. A. (1945). Amer. F. phys. Anthrop. 3, I.

Winn, B. (1943). Alaska Life, 6, 3 I.

Woodyatt, R. T. (1921). Arch. intern. Med. 28, 125.

Yule, R. F. (1948). Canad. med. Ass. F. 58, 287. 